\title{
Liberalismo À Moda Brasileira: o VelHo Problema do Capitalismo Politicamente ORIENTADO
}

\author{
Lenio Luiz Streck* \\ Danilo Pereira Lima**
}

"São estes os meus sentimentos e jamais concederei aos homens vis maiores honras que as merecidas tão-somente pelos justos.

Só quem quiser o bem de Tebas há de ter a minha estima em vida e mesmo após a morte".

Creonte (Sófocles, 1996, p. 204)

1 Introdução. 2 O pensamento liberal e as limitações do Estado. 3 O BNDES e as distorções do liberalismo brasileiro. 4. Considerações Finais. Referências.

\section{RESUMO}

O trabalho procura atacar os efeitos do Estado patrimonialista sobre a sociedade civil, ao destacar os prejuízos que esse modelo de dominação tradicional causa numa sociedade democrática. É um modelo que não consegue distinguir muito bem a esfera pública da esfera privada, comprometendo o funcionamento de uma República, já que os negócios privados se apoiam excessivamente em "parcerias" com Estado. Enfrentar o patrimonialismo é fazer que o liberalismo brasileiro tenha outro caráter, mais coerente com a democracia, com o constitucionalismo e com o livre desenvolvimento da sociedade civil. Essas questões serão abordadas neste artigo, com o intuito de realizar uma reflexão sobre o funcionamento do Estado brasileiro; a recepção que este fez do liberalismo; e as possibilidades de se instituir um regime republicano em terras brasileiras.

Palavras-chave: Liberalismo. Estamento. Patrimonialismo. Sociedade civil. Estado.

* Professor Titular do Programa de Pós-Graduação em Direito da Unisinos (RS). Doutor e Pós-Doutor em Direito; Ex-Procurador de Justiça (MP/RS). Presidente de Honra do Instituto de Hermenêutica Jurídica (IHJ).<lenio@unisinos.br>.

** Professor de Teoria Geral do Estado. Doutorando e Mestre em Direito Público pela Unisinos/RS. Bolsista Capes/Prosup. Membro do Grupo "Dasein - Núcleo de Estudos Hermenêuticos” (Unisinos). <danilopldireito@gmail.com>. 


\section{INTRODUÇÃO}

No ensaio Raízes do Brasil, escrito na década de 1930, Sérgio Buarque de Holanda enfrentou a concepção tradicional de Robert Filmer de que o Estado seria uma extensão da organização familiar, ao apontar que "não existe entre o círculo familiar e o Estado, uma gradação, mas antes uma descontinuidade e até oposição." Para sustentar esse posicionamento, Buarque de Holanda fez uma leitura original da tragédia Antígona, de Sófocles, ao apresentar Creonte como defensor dos interesses da comunidade política em oposição aos interesses familiares de Antígona. Nesse sentido, os dois personagens principais da tragédia apresentaram conceitos opostos de nomos (norma, lei). Enquanto Antígona sobrepôs o interesse familiar às leis da pólis; Creonte evocou os valores públicos da comunidade política em oposição aos interesses privatistas e afirmou que, "[...] se qualquer um tiver mais consideração por um de seus amigos que pela pátria, esse homem eu desprezarei." Assim, para o autor de Raízes do Brasil, "Creonte encarna a noção abstrata, impessoal da Cidade em luta contra essa realidade concreta e tangivel que é a família." ${ }^{3}$ Ou seja, Creonte nos ensina a importância do fortalecimento das instituições públicas para a formação e a preservação de um regime democrático, com um Estado despersonalizado.

Sem dúvida alguma, a originalidade deste ensaio foi fundamental para nos ajudar a compreender os muitos problemas oriundos de um país em formação, ao analisar, de uma forma diferenciada,

[...] as vicissitudes da construção de uma sociedade urbana a partir de experiências de vida associativa ilhadas no particularismo dos 'grupos primários', isto é, do círculo das relações imediatas e diretas, de pessoa a pessoa, como na família. ${ }^{4}$

Surgiu, assim, a tese do homem cordial, apresentada por Sérgio Buarque de Holanda como um verdadeiro obstáculo para a modernização do Brasil. De acordo com ele, a permanência da herança colonial impediria o predomínio da racionalidade na vida pública, já que esta se encontraria sempre sufocada pela visão afetiva própria da personalidade dos brasileiros, que, no caso, estariam menos propensos a utilizar a razão abstrata do que a paixão na condução dos assuntos de Estado. Ao mesmo tempo, o predomínio dessa visão afetiva também seria responsável pela formação de regimes políticos violentos e arbitrários, erguidos completamente fora da legalidade constitucional. Desse modo, "o desafio proposto para o futuro será exatamente o de substituir o personalismo, que fundamenta as oligarquias, pela racionalidade da vida pública, que pode fundamentar a democracia." ${ }^{5}$

O texto de Sérgio Buarque de Holanda é fundamental para a crítica do poder personalista predominante na política brasileira. Seu ensaio é considerado um clássico do pensamento político nacional. No entanto, as posições defendidas pelo autor pecam numa questão que, mais tarde, o próprio Sérgio Buarque de Holanda iria rever no conjunto de sua obra: a tentativa de analisar as características psicológicas peculiares do povo brasileiro por meio da tese do 
homem cordial. É como se houvesse uma essência fundante responsável pela formação de um caráter particular do povo brasileiro.

Foi para romper com esse modo de abordar os problemas do Brasil, que Dante Moreira Leite defendeu a sua tese de doutorado, em 1954, com o título de Caráter nacional brasileiro: estudo de ideologias e estereótipos. Nessa pesquisa, Dante procurou enfrentar os estereótipos presentes nos conceitos subjacentes ao caráter nacional, que aparecem em importantes autores do pensamento social brasileiro, como Alberto Torres, Oliveira Viana, Alfredo Ellis, Paulo Prado, Gilberto Freyre e Sérgio Buarque de Holanda, para citarmos apenas alguns dos autores analisados na obra. Para Dante, a psicologia do povo brasileiro pode ser considerada como o eixo principal dessa tradição intelectual, abordada criticamente a partir da psicologia social contemporânea ${ }^{6}$.

Apesar de Sérgio Buarque de Holanda dar relevância para aspetos importantes da vida social brasileira, seu ensaio permaneceu preso à ideia de características psicológicas nacionais que determinam a formação particular de um povo. Dessa maneira, ao demonstrar a inexistência de qualquer prova científica capaz de afirmar que um povo possa ter características psicológicas inexistentes em outro, Dante evidenciou a fragilidade da tese do homem cordial sustentada em Raízes do Brasil. É principalmente nesse aspecto que se encontram as contradições do ensaio clássico de Sérgio Buarque de Holanda, "[...] que continua válido, não por sua teoria global, mas por algumas observações parciais e reconstruções históricas de alguns episódios e de alguns aspectos da vida brasileira."

Por outro lado, em 1958, Faoro produziu um longo ensaio a respeito da formação do patronato político brasileiro, que propiciou um novo manejo dos diversos conceitos que Max Weber utilizava para analisar a realidade europeia. Diferentemente de Sérgio Buarque de Holanda, Faoro procurou explicar que as origens dos diversos problemas existentes na realidade política brasileira não estavam na personalidade particular de um povo, mas sim em outros elementos político-institucionais que tiveram seu nascedouro no século XIV, durante a formação do Estado português. ${ }^{8}$ Nesse sentido, os desvios que aconteciam na esfera pública deixaram de ser explicados como uma característica do caráter do povo brasileiro, para serem analisados como uma questão relacionada à estrutura de poder que os portugueses implantaram durante a colonização e que, após a chegada da família real em 1808, proporcionou a formação de uma dispendiosa máquina administrativa criada fundamentalmente para contemplar os membros mais seletos da aristocracia portuguesa, ${ }^{9}$ que, depois de abandonarem seus cargos e suas propriedades para fugirem do exército de Napoleão, continuaram a apoiar-se no erário público para sustentar a boa vida e os antigos privilégios possuídos na metrópole ${ }^{10}$.

A interpretação de Faoro toma como traço dominante da história do Brasil a tutela autoritária da sociedade pelo Estado. Para ele, essa situação contrariava a análise marxista ${ }^{11}$, ao demonstrar que o Estado não agia de maneira 
mais autônoma somente em momentos históricos excepcionais, numa situação em que as classes sociais alcançavam maior equilíbrio político. Por outro lado, a maneira como Faoro compreende a formação do Brasil também se coloca numa posição antagônica à tradição privatista sustentada por Oliveira Viana e Nestor Duarte, que, no caso, davam uma maior ênfase no poder dos grandes proprietários territoriais frente ao Estado. Segundo Faoro, as experiências políticas de Portugal e do Brasil haviam desmentido essas teses, proporcionando o nascimento de um Estado independente e autônomo, que se coloca sempre acima da própria nação. Em todos os períodos históricos, o estamento se comportaria como verdadeiro árbitro da sociedade. Assim, de acordo com Bernardo Ricupero e Gabriela Nunes, "[...] o maior problema do Brasil não é para Faoro a falta de poder do Estado, mas justamento o oposto: o poder estatal oprimindo a nação."12

Dessa forma, para Faoro, o Estado brasileiro foi formado por um estamento patrimonialista adequado ao modelo tradicional de dominação política, capaz de se amoldar a todos os momentos de transição e perpetuar um controle político no qual o exercício do poder não é uma função pública, mas simplesmente objeto de apropriação de interesses privados. Segundo ele, esse estamento burocrático jamais correspondeu àquela burocracia moderna, como um aparelhamento neutro, constituído em carreira administrativa e que sempre deve atuar com padrões bem assentados de racionalidade e legalidade. ${ }^{13}$ Para Faoro, o estamento burocrático encontra-se posicionado acima dos demais setores da sociedade brasileira, dedicando-se unicamente a tomar conta dos cargos oferecidos pela administração pública e sempre se posicionando no melhor lugar para a defesa de interesses meramente privados, já que, para esse "nobre" setor, o público e o privado nunca estão separados.

Esse modelo de organização do Estado gerou uma forma particular de desenvolvimento econômico, chamada por Faoro de capitalismo politicamente orientado. Nele, os riscos da atividade privada, que deveriam ocorrer no âmbito do funcionamento normal do mercado, não se estabelecem inteiramente por causa da própria sociedade civil, conforme o posicionamento do pensamento liberal. Ao contrário, no Brasil, é o Estado que se coloca como principal patrocinador dos negócios privados, assumindo uma postura nada republicana. Assim, "a trama entre Estado e burocracia, por um lado, e sociedade civil, classes e mercado pelo outro é mais complexa, sendo difícil admitir uma autonomia tão forte entre um dos dois polos do binômio." 14

Dessa forma, a partir da atuação do Banco Nacional de Desenvolvimento (BNDES), o presente artigo pretende analisar as incoerências da elite política brasileira na recepção do pensamento liberal. Seria mesmo liberal a maneira como o importante banco estatal distribui ou investe seus recursos na atividade privada? O liberalismo brasileiro estaria contraditoriamente fundamentado numa atuação forte do Estado em negócios privados? E mais, a aplicação desses recursos segue algum critério constitucional e republicano exigido por um Estado Democrático de Direito? Estes e outros questionamentos serão abordados nos 
próximos tópicos, com o intuito de realizar uma reflexão sobre o funcionamento do Estado brasileiro; a recepção que este fez do liberalismo; e as possibilidades de se instituir um regime republicano em terras brasileiras.

\section{O PENSAMENTO LIBERAL E AS LIMITAÇÕES DO ESTADO}

A modernidade inaugurou uma nova organização política por meio da criação do Estado. Essa mudança teve como consequência a ruptura com as formas anteriores de estabelecimento do poder político, ainda envolvidas em fundamentações teológicas e na pessoalidade do governante ${ }^{15}$. A partir da modernidade, tornou-se necessário separar a política da religião; superar a fragmentação do poder político, presente no medievo; e afastar o controle pessoal das instituições políticas, conforme a teoria dos dois corpos do rei, começou a realizar no contexto inglês ${ }^{16}$. Nasceu, assim, o Estado.

Seu aparecimento ocorreu primeiramente como Estado absolutista, ao apresentar uma resposta aos diversos problemas e contradições oriundas da desintegração da sociedade feudal. Durante a Idade Média, o feudalismo se destacou como uma unidade orgânica de economia e dominação política, baseado em uma cadeia de domínios parcelares na qual o exercício do poder político se encontrava completamente fragmentado. Não havia Estado, apenas a Igreja possuía certa unidade institucional, o que acabou favorecendo seu domínio político ${ }^{17}$. As relações sociais, entre os membros da aristocracia, eram marcadas essencialmente pelo dever de vassalagem e de serviço militar, exercidas diretamente pelos senhores feudais. A aristocracia não trabalhava diretamente em suas terras e se dedicava exclusivamente às atividades militares; enquanto, do outro lado, o servo estava ligado permanentemente à terra, sendo obrigado a trabalhar alguns dias da semana apenas para pagar as obrigações devidas ao seu senhor.

No início da Idade Moderna, essas relações sociais se desestruturaram completamente, colocando em crise toda a estrutura política, econômica e social do feudalismo. Segundo Nicola Matteucci, essa crise do complexo modelo de organização feudal foi motivada por distintos fatores: o crescimento econômico, que favoreceu o nascimento das novas classes sociais e o rompimento com o estático equilíbrio da sociedade estamental; a nova cultura humanista, que passou a situar o indivíduo no centro do mundo, tornando-o insensível diante de uma ordem social natural correspondente a uma ordem celeste; e o surgimento do Estado, que se afirmou como uma máquina construída racionalmente ${ }^{18}$.

Nesse sentido, o Estado absolutista veio para superar a ultrapassada estrutura social e política do medievo, colocando-se em um nível superior em comparação com qualquer instituição existente naquela época, já que a monopolização do poder político e da força militar permitiu uma maior uniformidade legislativa e administrativa frente às várias formas particularistas de exercício do poder ${ }^{19}$. Com a formação de um moderno quadro burocrático e um exército regular, o Estado absolutista se transformou no único sujeito político com ca- 
pacidade para regular o comportamento dos indivíduos e das forças sociais, ao oferecer melhores condições para a pacificação interna e externa ${ }^{20}$.

É importante destacar que a transição do medievo para a idade moderna não ocorreu de maneira tranquila. No século XVI, a ordem estabelecida pelo feudalismo entrou em plena decadência, e o fim da unidade da Igreja Católica, a partir da reforma protestante, acabou por agravar ainda mais o quadro de extrema violência desse período. Diversas facções religiosas passaram a se digladiar, deixando a sociedade em uma anarquia generalizada de guerras civis, duelos e assassinatos. De acordo com Reinhart Koselleck, "[...] a pluralização da Ecclesia Sancta foi um fermento para a depravação de tudo o que antes era coeso: famílias, estamentos, países e povos."21

A instabilidade social, criada pelos partidos religiosos e pelas igrejas intolerantes, exigia uma solução capaz de apaziguar essas lutas. Somente um poder político e militar, colocado acima das opiniões dos súditos, teria condições reais para pacificar os homens. Desse modo, a solução elaborada pelos teóricos do Estado absolutista ocorreu no sentido de romper com a prevalência de qualquer facção religiosa sobre os interesses estatais, ao exigir a submissão dos diferentes partidos religiosos a uma única autoridade soberana, já que, tanto no plano interno, quanto no plano externo, o Estado não reconheceria nenhuma instancia superior a sua própria ordem. Desse modo, Nicola Matteucci afirma que,

En el quinientos, sin embargo, la paz social no se identifica ya con la recta administración de la justicia por el rey, sino con la necesidad de superar una guerra civil surgida por motivos religiosos. Era necesaria la primacía de la política y del Estado (una unidad superior y neutral), y del orden mundano que éste representaba, sobre sectas religiosas intolerantes que provocaban desordenes en nombre de la primacía de la religión; se necesitaba crear um campo de acción racional en el que todo - de la religión a la economía -fuese juzgado con base en la utilidad del Estado, con base en um frio cálculo racional de las consecuencias de cada acción. ${ }^{22}$

Assim, diante das pressões do novo ambiente social, as mudanças políticas acabaram por conduzir o Estado a uma incipiente racionalização, motivado principalmente pela grande insuficiência dos velhos instrumentos políticos para satisfazer as novas demandas diplomáticas, militares e financeiras. A formação dos exércitos regulares exigiu maiores recursos, já que os Estados se transformaram em verdadeiras máquinas de guerra. Era uma situação que exigia um sistema fiscal muito mais eficiente e organizado. Desse modo, a construção de uma estrutura burocrática para realizar a tributação entre os súditos e arrecadar maiores recursos financeiros foi fundamental para a cobertura das novas despesas militares.

Foi nesse ambiente político conturbado que Thomas Hobbes apresentou o Leviatã (1651), obra fundamental para o desenvolvimento da filosofia política na modernidade. Nela, o Estado foi apresentado como produto da razão ${ }^{23}$, 
construído artificialmente pelos indivíduos para preservar o maior bem existente entre eles, que é a vida, pois, segundo Hobbes,

[...] durante o tempo em que os homens vivem sem um poder comum capaz de os manter a todos em respeito, eles se encontram naquela condição a que se chama guerra; e uma guerra que é de todos os homens contra todos os homens. ${ }^{24}$

Ao contrário de Aristóteles, a sociedade política hobbesiana não foi apresentada como uma organização natural, mas sim como fruto de um pacto voluntário entre os homens. ${ }^{25}$

Por meio desse contrato, os homens naturais deveriam se constituir em sociedade política, ao transferir ao soberano o direito de exercer todo o poder. Para isso, Hobbes propôs a formação de uma sociedade política com um poder soberano indivisível e integral, já que o surgimento de um governo misto, com o poder exercido de maneira fragmentada, poderia colocar em risco a existência do Estado. Para que o poder soberano tivesse condições de se impor, ele defendeu que a realização do pacto deveria ocorrer apenas entre os homens naturais, deixando unicamente de fora aquele que mais tarde ficaria encarregado de exercer o poder soberano.

Por esse motivo, todos os indivíduos deveriam abrir mão de seus respectivos direitos naturais, pois a preservação de uma pequena parte deles colocaria em risco a paz e a segurança oferecidas pelo Estado. Assim, com a formação da sociedade política, a liberdade de todos os súditos deveria ser transferida imediatamente para o Estado, instituído como detentor de todo poder necessário para impedir a guerra entre os indivíduos. Diante do constante perigo da violência generalizada, o Estado foi elaborado para pacificar as relações humanas, por meio da atuação de um poder soberano colocado acima das contradições políticas e religiosas daquele tempo tão conturbado. Dessa forma, segundo Thomas Hobbes:

[...] pela arte é criado aquele grande Leviatã a que se chama Estado, ou Cidade (em latim Civitas), que não é senão um homem artificial, embora de maior estatura e força do que o homem natural, para cuja proteção e defesa foi projetado. E no qual a soberania é uma alma artificial, pois dá vida e movimento ao corpo inteiro; [...] a justiça e as leis, uma razão e uma vontade artificiais; a concórdia é a saúde; a sedição é a doença; e a guerra civil é a morte. ${ }^{26}$

Portanto, a teoria hobbesiana se preocupou essencialmente com a antítese existente entre a unidade em torno de um único poder soberano e a anarquia social, presente nos lugares onde o poder se encontrava completamente fragmentado. $\mathrm{O}$ risco da dissolução da autoridade e a fragmentação política apareciam como questões prejudiciais para a boa formação do Estado. Em concordância com Hobbes, apenas a constituição de um poder comum, capaz de monopolizar o uso da força, teria condição de salvar os homens de sua destruição, já que, somente com a criação do Leviatã, o homem encontraria sua necessária proteção. 
Dessa forma, se, num primeiro momento, a preocupação da teoria política moderna se concentrou no problema do estabelecimento da organização estatal; logo depois, os teóricos liberais colocaram em evidência o problema da limitação do poder político, exercido no âmbito do Estado. E isso, de acordo com o pensamento liberal, deveria passar necessariamente pela separação entre Estado e sociedade civil, pois o poder político não estava autorizado a interferir em todos os âmbitos da vida privada. Assim, é possível perceber a origem histórica dessa corrente de pensamento na luta política dos ingleses contra Jaime II, que resultou na Revolução Gloriosa de 1688 e na supremacia do Parlamento. Segundo Merquior, "os objetivos dos vencedores da Revolução Gloriosa eram tolerância religiosa e governo constitucional. Ambos tornaram-se pilares do sistema liberal, espalhando-se com o tempo pelo ocidente." ${ }^{\text {27 }}$

O projeto de um governo limitado, por meio de uma aliança entre a lei e a liberdade, foi visto por diversos intelectuais dos séculos XVII e XVIII como o ideal para o estabelecimento de uma sociedade mais próspera. Teóricos, como John Locke e Montesquieu, procuraram criar fórmulas institucionais tanto para a limitação da autoridade quanto para uma divisão equilibrada do poder, sendo mais tarde recepcionados com sucesso pelos pais fundadores da democracia estadunidense. Todos eles acreditavam que, somente por esse caminho, as liberdades individuais estariam asseguradas contra qualquer investida autoritária do Estado.

Contudo, é importante destacar que as conquistas liberais, originárias de um poder político limitado, restringiram-se, num primeiro momento, apenas a uma elite composta por homens brancos e proprietários ${ }^{28}$. Desse processo estavam excluídos os negros, transformados em escravos; os brancos pobres, envolvidos numa jornada extenuante de trabalho; e as mulheres, limitadas apenas aos afazeres domésticos e impedidas de qualquer participação política. O sufrágio universal era visto com enorme desconfiança pelos donos do capital, que há pouco haviam superado o poder da aristocracia, mas, ao mesmo tempo, afastavam-se das classes populares com enorme receio. ${ }^{29} \mathrm{O}$ medo das massas, propagado pela burguesia, fez que o liberalismo, num primeiro momento, ficasse restrito apenas a cidadãos prósperos, seguindo o posicionamento que Benjamin Constant havia denominado de "le juste milieu."

Mesmo diante dessas contradições, é inegável que o pensamento liberal ofereceu uma grande contribuição para o controle constitucional do poder político, ao elaborar mecanismos institucionais formidáveis para a formação do Estado de Direito. Nesse sentido, em oposição ao argumento hobbesiano, de que os indivíduos somente encontrariam uma vida pacífica por meio de um Estado absoluto, Locke apresentou sua objeção em defesa de uma monarquia constitucional, ao rechaçar a ideia de um Estado presente em todas as esferas da vida social. Segundo David Held, "para Locke, la actividad política es instrumental; garantiza el marco o las condiciones para la libertad, de modo que los fines privados de los individuos puedan ser realizados en la sociedad civil." ${ }^{31}$ Com isso, o governo passa a depender do consentimento e da confiança dos indivíduos que, no caso, não abririam mão 
de seus direitos naturais, com exceção de um, o direito de elaborar e fazer cumprir as leis. Este deveria ser transferido ao controle do Estado. ${ }^{32}$

Diante do desenvolvimento do capitalismo comercial e das novas reivindicações do pensamento liberal, contrapostas ao Estado absolutista de Hobbes, surge a necessidade de separação entre poder político e sociedade civil, ou seja, a esfera de atuação do Estado deve se restringir à criação e à defesa de uma estrutura política, que permita aos cidadãos desenvolver suas vidas particulares e suas atividades econômicas, livres do perigo da violência e das interferências indevidas do Leviatã. Assim, de acordo com David Held:

La idea de la libertad frente a una autoridad política envolvente ('libertad negativa', tal como ha sido llamada) conformó el ataque a partir de finales del siglo XVI contra los antigos regímenes de Europa y fue el complemento perfecto para la creciente sociedad de mercado, ya que la libertad de mercado implicaba, en la práctica, dejar que fueran las inciativas privadas en la producción, distribución e intercambio las que determinaran las circunstancias de la vida de las personas. ${ }^{33}$

$\mathrm{Na}$ análise que Marx realiza do capitalismo, a delimitação do papel da sociedade civil fica bem clara quando o autor demonstra que, nesse âmbito, deveriam se concentrar as relações econômicas, sendo estas independentes ou, até mesmo, contrapostas à esfera das relações da sociedade política. ${ }^{34} \mathrm{De}$ acordo com Bobbio,

[...] tanto a "sociedade natural" dos jusnaturalistas, quanto a "sociedade civil" de Marx indicam a esfera das relações econômicas intersubjetivas de indivíduo a indivíduo, ambos independentes, abstratamente iguais, contraposta à esfera das relações políticas, que são relações de domínio. ${ }^{35}$

Assim, para Marx, a origem e o funcionamento da sociedade civil deveriam ser buscados sempre na economia política.

Nesse sentido, o aparecimento da sociedade civil representou o início do processo de diferenciação entre Estado e sociedade na modernidade, ao expressar as transformações econômicas e políticas pelas quais vinham passando a Europa e os Estado Unidos, respectivamente nos séculos XVII e XVIII. Para o pensamento liberal, essa separação foi fundamental para o fomento da liberdade burguesa e do progresso capitalista. Na verdade, o pensamento liberal estava corrigindo o antigo erro presente na tradução latina de "político" como "social", já que, desde os gregos, a esfera privada da organização familiar estava colocada em oposição à organização política da pólis. Segundo Arendt,

Esta substituição inconsciente do social pelo político revela até que ponto a concepção original grega de política havia sido esquecida. Para tanto, é significativo, mas não conclusivo, que a palavra 'social' seja de origem romana, sem qualquer equivalente na língua ou no pensamento grego. ${ }^{36}$ 
Entre os gregos, a associação política se opunha à associação privada, cujo centro era constituído pela esfera doméstica. O cidadão da pólis considerava a política - desenvolvida na Assembleia - como a sua principal atividade e colocava a vida privada numa posição inferior, já que aquilo que era comum (koinon) era superior ao que the era próprio (idion). Dessa forma, tudo aquilo que havia sido construído com base na organização familiar, como o culto à deusa Héstia, teve de ceder lugar ao predomínio do político, como o culto à religião olímpica. Outro exemplo de separação entre o doméstico e o público pode ser observado na posição que os gregos mantinham em relação ao trabalho manual, já que tudo que estivesse relacionado com a manutenção do indivíduo - o econômico - também estava colocado fora dos assuntos políticos. Assim, ao afirmar que o homem era um animal político (bios politikos), Aristóteles não estava meramente sustentando a sociabilidade biológica dos homens, presente também em outras espécies de animais; na verdade, o filósofo procurou demonstrar que o homem grego estava completamente envolvido com as questões de sua comunidade política, ou seja, a pólis, e que os assuntos privados não estavam presentes no domínio público. ${ }^{37}$

Com um sentido específico diferente dos gregos, o pensamento liberal também separou o poder político da atividade econômica, resguardando a esfera privada de qualquer interferência indevida por parte do Estado. De acordo com essa corrente, caberia ao Leviatã oferecer segurança à propriedade e deixar que a iniciativa privada, por meio de sua própria conta e risco, cuidasse de seus negócios, ciente de que, no sistema capitalista, o imponderável em qualquer investimento é parte integrante das relações econômicas. Para os grandes cânones do liberalismo - como Adam Smith, em seu livro A riqueza das nações - o empresário não deve enxergar o poder político como seu principal parceiro nos negócios. Assim, para eles, o Estado teria apenas a responsabilidade de garantir a todos, "[...] em condições de plena liberdade, o direito de lutar pelos seus interesses como melhor entender." ${ }^{38}$ Contudo, no Brasil, o pensamento liberal tomou outro caráter...

\section{O BNDES E AS DISTORÇÕES DO LIBERALISMO BRASILEIRO}

Diferentemente das formulações teóricas do pensamento liberal, presentes nos contextos europeu e estadunidense, no Brasil, o liberalismo tomou um rumo completamente diverso, ao colocar o Estado na posição de principal parceiro e "incentivador" da iniciativa privada. De acordo com esse liberalismo sui generis, o Estado se coloca como o maior patrocinador das empresas privadas, com a condição de que estas, de alguma forma, estejam associadas ao estamento burocrático. Esse modelo patrimonialista de dominação do Estado, analisado primeiramente por Faoro ${ }^{39}$, é responsável por aquilo que ele chamou de "a viagem redonda" ${ }^{40}$ no estabelecimento e no desenvolvimento das instituições políticas brasileiras, dando a impressão de que, apesar das grandes mudanças, sempre voltamos ao mesmo lugar, submetidos a uma camada governante burocrática que se sobrepõe a uma débil sociedade civil. Segundo ele, 
Essa circunstância, se observada, retira a estranheza de, num salto às vezes secular, reencontrar-se o espectador com a reprise de um espetáculo já visto e que deveria estar arquivado nos anais dos cronistas. ${ }^{41}$

Nesse sentido, as classes sociais não seriam o fator determinante das relações políticas e sociais; pelo contrário, o antagonismo preponderante no Brasil se encontra na oposição entre governantes e governados, estando os últimos debilitados diante de uma ordem política autocrática. Reconhecido como um subtipo da dominação tradicional, presente na sociologia weberiana, Faoro demonstra que, diferentemente da dominação racional legal - que tem como base a racionalidade formal -, o patrimonialismo se apoia numa racionalidade material, na qual predomina a ação burocrática no sentido de regulamentar e ordenar a economia. ${ }^{42}$ Assim, segundo Faoro:

A racionalidade formal [...] coincide com o capitalismo, no qual se levam em conta, no seu funcionamento, a calculabilidade e a previsibilidade das ações sociais. A dominação patrimonial, ao contrário, por incompatível com a igualdade jurídica e as garantias institucionais contra o arbítrio, torna o indivíduo dependente do poder que lhe dita, pela definição de valores, a conduta. Aponta, em consequência, para um sistema autocrático, que, em lugar de se desenvolver segundo uma ordem em que a sociedade é autônoma, afirma a dependência ao poder da autoridade. ${ }^{43}$

O Brasil tem características dos dois tipos de dominação, o que faz que a ordem patrimonialista se esconda por debaixo de uma estrutura nominalmente racional-burocrática. Com raízes na revolução de Avis - em Portugal -, o Estado patrimonialista brasileiro, formado após o processo de independência, também tomou emprestado alguns elementos do mundo capitalista inglês, por exemplo, o liberalismo. Contudo, o que acabou predominando foi o modelo tradicional de dominação política, com a sociedade civil constantemente submetida às imposições vindas de cima; uma característica institucional que explica a dificuldade do Brasil, ao longo de sua história, de recepcionar os mecanismos constitucionais de limitação do poder.

Faoro destaca que o patrimonialismo não está presente em qualquer forma de intervenção estatal na economia. Para que exista o patrimonialismo, é necessário que a empresa privada desenvolva suas atividades sempre na dependência do "patrocínio" do poder público, no sentido de que "a empresa é, dessa forma, uma iniciativa particular viável por meio da dádiva pública, obtida por meios legais ou ilícitos." ${ }^{4}$. Dessa forma, o liberalismo gerado pelo Estado patrimonialista se apresenta com graves incongruências, tendo dificuldade para limitar a esfera de atuação do poder público e, ao mesmo tempo, separar o que pertence à comunidade política de interesses meramente privados.

Nessas circunstâncias, uma análise das instituições políticas brasileiras, a partir da sociedade civil de Hegel, acaba por ocultar o domínio do Estado sobre 
a sociedade e tem dificuldade para compreender a excessiva dependência do empresário em relação ao estamento, que, no caso, controla o poder público. Ao contrário do referencial teórico marxista ${ }^{45}$, a estrutura econômica e a luta de classes não são suficientes para a compreensão da formação e do funcionamento do Estado patrimonialista. No Brasil, é a organização política que se sobrepõe à sociedade civil. Assim, com o aparelho administrativo nas mãos do governante e de seu quadro burocrático, os recursos públicos são distribuídos para um seleto grupo de empresários, sem que o Estado apresente qualquer consideração pelos parâmetros constitucionais. As relações se desenvolvem apenas com base no compadrio.

O personalismo nas relações públicas é um aspecto importante para a compreensão do Estado patrimonial, que, por meio do estamento burocrático, concede "favores" ao empresariado a partir do erário público. No entanto, a pessoalidade presente no patrimonialismo de Faoro, não é a mesma do patriarcalismo presente em diversos intérpretes do Brasil, como é o caso de Gilberto Freyre $^{46}$. Se, no caso do patrimonialismo, a dificuldade em separar a esfera pública da esfera privada está associada à atuação do corpo político-burocrático, que, diuturnamente, se apropria da máquina pública; no caso do patriarcalismo, a apropriação do público pelo privado ocorre a partir do núcleo familiar. Com isso, a compreensão do liberalismo no Brasil toma sentidos bem diferentes. Enquanto, no patriarcalismo, as instituições liberais não passam de mera ficção; no patrimonialismo, ocorre a penetração de um liberalismo muito peculiar, que, embora desfigurado, está presente no funcionamento de algumas instituições. ${ }^{47} \mathrm{E}$ aquilo que o presente trabalho denominou de um liberalismo à moda brasileira.

É por isso que o pensamento conservador sempre enxergou no Estado a solução para os problemas brasileiros. Em Oliveira Viana, o Estado forte é apresentado como resposta ao controle do poder político pelos clãs, que, no caso, estavam ligados ao latifúndio e eram responsáveis pela fragmentação do poder estatal. ${ }^{48}$ Contudo, Faoro tomou caminho totalmente diverso em Os donos do poder. Ao destacar e analisar o papel do patrimonialismo na formação das instituições políticas brasileiras, ele demonstrou que o Estado não pode ser considerado como um "bem em si mesmo" para o desenvolvimento das relações econômicas e sociais. A presença excessiva do poder político, na sociedade civil, deve ser visto como um entrave considerável para o estabelecimento de um regime constitucional. Os exemplos da ditadura Vargas (1930-1945) e da ditadura civil-militar (1964-1985) confirmam essa tese. Nesses dois casos, uma concepção autoritária do Estado serviu para levar à frente uma modernização completamente desconectada com o constitucionalismo. Por isso, para Fernando Henrique, "[...] a predominância burocrático-estatal mais leva água ao moinho do conservadorismo tradicional do que representa um avanço na democratização das instituições e da sociedade." ${ }^{49}$

Nesse sentido, uma análise das relações do BNDES junto ao empresariado é fundamental para a compreensão do tipo de liberalismo gerado pelo Estado patrimonialista brasileiro. O Banco estatal tem sido o principal parceiro e pa- 
trocinador de setores da iniciativa privada mais próximos dos círculos de poder, instalados em Brasília. E isso independe da coloração partidária do governo. Tanto nas administrações lideradas pelo PSDB, como também nas do PT, são encontrados fartos exemplos de "incentivo" estatal para o desenvolvimento de algumas empresas, pois, em concordância com Faoro,

Todos os gatos se tornam pardos, apesar das distinções, com a ascensão do poder político. Fora do poder, o conservador namora a ideologia liberal. No poder, o liberal manifesta-se com a inabalável fé dos convertidos. ${ }^{50}$

Assim, esse liberalismo distorcido, presente na atuação do Banco estatal, pode ser observado em duas situações específicas: a participação do BNDES no processo de privatização realizado pelo governo do presidente Fernando Henrique Cardoso (1994-2002); e as relações do Banco estatal com a empresa Friboi durante os governos do presidente Luis Inácio Lula da Silva (2002-2010) e da presidente Dilma Rousseff (2010-2014).

No primeiro caso, o Programa Nacional de Desestatização, criado pelo governo do PSDB, foi responsável pela implementação do ideário neoliberal no Brasil; com o detalhe importante de que a compra das empresas estatais acabou sendo realizada por meio do financiamento de um Banco estatal, o BNDES. Foi por meio do próprio Estado que o neoliberalismo aportou em terras brasileiras, contrariando completamente o programa de privatizações implementado pelo governo de Margaret Thatcher, na Inglaterra. Os leilões, organizados pelo governo brasileiro, se transformaram em negócios altamente lucrativos para as empresas privadas interessadas em adquirir as empresas públicas, já que estas primeiramente recebiam investimentos do governo, para depois serem vendidas a um preço muito baixo, via financiamento do BNDES.

No processo de privatização do setor de telecomunicação foi anunciado pelo governo FHC que as estatais haviam sido vendidas por $\mathrm{R} \$ 22,2$ bilhões, o que, na época, pareceu um excelente negócio para o Estado. Contudo, o que o governo não deixou claro foi que o erário público recebeu apenas $\mathrm{R} \$ 8,8$ bilhões, ou $40 \%$ daquele valor, sem considerar que metade da entrada foi financiada pelo BNDES, nos casos em que o comprador era uma empresa nacional ou apenas fizesse parte do consórcio. ${ }^{51}$ Como se não bastasse todo esse apoio do Estado, antes do anúncio das privatizações, o governo já havia aumentado as tarifas de diversos serviços públicos, entre eles, a telefonia, com um reajuste de $500 \%$ a partir de novembro de $1995 .{ }^{52}$

E a "parceria" do Estado com a iniciativa privada não ficou apenas no financiamento do BNDES para a compra das estatais. As empresas compradoras receberam mais apoio do Estado para administrar seus novos negócios. Para cumprir o acordo feito com o governo, no sentido de ampliar os investimentos nas antigas empresas públicas, as empresas privadas receberam empréstimos bilionários do BNDES. Nesse sentido, após constantes problemas no fornecimento de energia elétrica no estado do Rio de Janeiro, o Banco estatal garantiu 
a Light um empréstimo de R $\$ 730$ milhões. A Companhia Siderúrgica Nacional recebeu o montante de $\mathrm{R} \$ 1,1$ bilhão do Banco. ${ }^{53}$ Dessa forma, onde os neoliberais defenderam menos Estado surgiu mais Estado, um verdadeiro paradoxo para os defensores da privatização no Brasil.

A mesma postura do BNDES pode ser observada nos governos do PT. Mudam-se os partidos, mas a lógica de desenvolvimento econômico, do capitalismo politicamente orientado continua a funcionar como um verdadeiro guia para as ações do Banco. Empréstimos e investimentos feitos sem nenhum critério objetivo, mas apenas com base em relações personalistas desenvolvidas entre setores da iniciativa privada e membros do estamento burocrático, continuam a acontecer abertamente nos círculos de poder em Brasília. Essa é a melhor maneira para se compreender a rápida ascensão da empresa Friboi no cenário nacional. Pelo visto, o segredo do seu crescimento está na sua proximidade com os governos Lula e Dilma.

Um frigorífico nascido no interior de Goiás e completamente desconhecido até a década passada, atualmente se encontra entre as maiores empresas privadas do Brasil, com um faturamento equivalente a $\mathrm{R} \$ 9$ bilhões em 2013 . $\mathrm{O}$ que, para muitos, poderia ser interpretado como resultado do empreendedorismo da família Batista, na verdade, oculta mais um exemplo de sucesso empresarial por meio de uma grande parceria com a máquina pública. Incluída entre os "campeões nacionais" pelo BNDES - uma "política pública" que beneficia grandes empresas -, parcela considerável da República continua sem saber que tipo de benefício alcançará por meio de tal investimento.

Nos últimos anos, o BNDES injetou R \$ 8,1 bilhões na empresa, por meio de capitalização, transformando-se em sua sócia com $24 \%$ das ações. Com tamanho investimento, a Friboi gastou R\$ 13,5 bilhões em aquisições, incorporações ou arrendamentos, no Brasil e no exterior. Com isso, as ações da empresa obtiveram em 2013 um crescimento 24 vezes maior do que havia sido alcançado em 2006. Sua receita passou a ocupar o segundo lugar entre as maiores empresas privadas no Brasil, ficando atrás apenas da Companhia Vale do Rio Doce. ${ }^{54}$ A empresa da família Batista pode ser considerada um exemplo de sucesso econômico via Estado. Ascensão alcançada por meio do velho capitalismo politicamente orientado.

Esses dois exemplos ilustram muito bem o modelo de desenvolvimento capitalista predominante no Brasil, fruto de um Estado patrimonialista que subvenciona empresas próximas ao estamento burocrático. Nesse sentido, o segredo do sucesso, alcançado por alguns setores da iniciativa privada, se encontra sempre interligado ao Estado. Isso ajuda a compreender as desventuras do liberalismo pátrio, continuamente vacilante na defesa de um Estado de direito capaz de limitar as atividades do governo. Por isso, segundo Faoro, "um liberal, entre nós, está sempre pronto a se refugiar na fortaleza conservadora, quando em risco os privilégios de uma classe. ${ }^{55}$ Ao ligarem-se confortavelmente à máquina pública, preferem não arriscar suas regalias. $O$ Estado patrimonialista se comporta como sucedâneo da sociedade civil. E quando surge a possibilidade 
de sua superação, com a promulgação de uma Constituição democrática, a história se repete como tragédia, com o reaparecimento do velho capitalismo politicamente orientado. Assim, apesar das grandes transformações institucionais após a redemocratização, de alguma maneira, sentimos que voltamos ao mesmo ponto. Aí estão os meandros e as sutilezas do liberalismo à moda brasileira.

\section{CONSIDERAÇÕES FINAIS}

A Teoria do medalhão, de Machado de Assis, é um conto que nos ajuda a compreender as incongruências do liberalismo brasileiro. Nesse texto, o pai explica a Janjão o caminho e as atitudes que este deveria assumir para alcançar as posições sociais mais promissoras, expondo os ensinamentos daquilo que ele chamaria de teoria do medalhão. Uma das regras, segundo ele, era evitar qualquer consistência teórica nas opiniões políticas. De acordo com a sua teoria, "uma vez entrado na carreira, deves pôr todo o cuidado nas ideias que houveres de nutrir para uso alheio e próprio. O melhor será não as ter absolutamente [...]." ${ }^{156}$ Assim, Janjão deveria evitar qualquer coerência ideológica, não assumindo posições políticas que se fechassem completamente em relação a outros grupos. Sobre a participação do filho em partidos políticos, o pai advertiu, "podes pertencer a qualquer partido, liberal ou conservador, republicano ou ultramontano, com a cláusula única de não ligar nenhuma ideia especial a esses vocábulos [...]." ${ }^{57} \mathrm{Ou}$ seja, deveria ser conservador ou liberal conforme as conveniências do momento.

Esses ensinamentos fizeram muito sucesso entre os liberais brasileiros, ao ponto de encontrarmos, no Império, setores do parlamento que, apenas nas aparências, incorporavam as posições políticas mais avançadas da Europa, mas, no cotidiano, estavam sempre prontos a defender uma monarquia despótica, o trabalho escravo e o esmagamento da sociedade civil pelo Estado. Com o aparecimento da República, o liberalismo não deixou de ser apenas um verniz entre os políticos. Esteve bem distante da realidade nacional diante dos golpes de Estado - contra o comunismo e em defesa da democracia -, da falta de compromisso com a defesa do constitucionalismo e, mais uma vez, da presença de parcerias nada republicanas dos grandes empresários com o Estado. Assim, em vez de um liberalismo crítico em relação ao autoritarismo estatal, o que predominou foi um liberalismo completamente destoante do que estava sendo construído pelos teóricos europeus e estadunidenses.

Esse é o resultado da formação e da permanência de um Estado patrimonialista, que, obviamente, se encontra deslocado em relação a temas muito caros ao pensamento liberal, como a defesa da democracia, da sociedade civil e dos limites constitucionais ao exercício do poder. A continuação de um modelo de dominação tradicional, tão bem analisando por Faoro, em Os donos do poder, tem dificultado a aplicação das ideias liberais no Brasil. Se, em alguns aspectos, como no caso do estabelecimento de um regime constitucional, o Brasil alcançou certo avanço, com a formação de instituições políticas relativamente estáveis após 1988; por outro lado, a parceria entre grandes empresários e estamento 
burocrático - sempre em detrimento da República - continua sendo um grave obstáculo para o cumprimento das promessas constitucionais do Estado Democrático de Direito.

É como se, no Brasil, houvesse um Estado pródigo somente para alguns grupos econômicos, sempre patrocinados, em seus negócios privados, pelo erário público. Contudo, no momento em que esse mesmo Estado deveria servir ao conjunto da comunidade, realizando as políticas públicas previstas pela Constituição, os recursos desaparecem. Dessa forma, para um setor da sociedade, o Estado se transforma num Oasis; para outro, o Estado se transforma num peso insuportável, ao ponto de prejudicar o livre desenvolvimento das pessoas.

A incoerência do liberalismo brasileiro está no modelo peculiar de capitalismo gerado pelo Estado patrimonialista. É o capitalismo politicamente orientado. Nesse modelo de desenvolvimento, a iniciativa privada somente alcança o sucesso econômico por meio do patrocínio estatal, garantido por intermédio do estamento burocrático. $\mathrm{O}$ Estado é sempre a fonte segura para qualquer tipo de investimento privado. Os recursos públicos são instrumentalizados em benefício de empresários que não conseguem manter seu próprio negócio longe da máquina pública. Para estes, sem a ajuda do Estado, não existe crescimento econômico possível.

No entanto, superar o modelo patrimonialista não é o mesmo que defender a indiferença do Estado com relação ao mercado. $O$ liberalismo não sustenta, necessariamente, uma completa ausência do Estado em assuntos econômicos. Em correntes significativas do pensamento liberal - como é o caso de Faoro -, existe uma defesa muito clara em favor da intervenção política para regulamentar o mercado e impedir que o capital tome conta de tudo. Inclusive, a excessiva desregulamentação da economia foi a maior responsável pela crise que afetou a Europa e os Estados Unidos nos últimos anos. Num período de domínio do capital financeiro, seria temerário defender um mercado livre de qualquer regulamentação política.

A problemática relação entre Estado e iniciativa privada não tem relação com as discussões sobre a regulamentação política do mercado; mas sim com o patrocínio que os empresários sempre recebem do poder público para poder desenvolver seus próprios negócios. Não existe empreendedorismo no Brasil. Por trás do sucesso de algumas empresas, sempre está o Estado, por meio do BNDES. Esse é o caso da Friboi, um frigorífico que até a década anterior era completamente desconhecido e que, de repente, desponta entre as maiores empresas privadas do país. Os apressados poderiam imaginar que o sucesso da empresa estaria relacionado apenas com a competência de seus proprietários, no entanto uma rápida investigação é capaz de demonstrar que a Friboi é mais um caso de sucesso empresarial alcançado pelas mãos do Estado.

Outro caso interessante foi o recente processo de privatização aplicado pelos neoliberais brasileiros. Aqueles que deveriam demonstrar a maior ojeriza 
em relação à intervenção do Estado na economia caíram num grande paradoxo. O BNDES financiou a compra da maior parte das empresas estatais, ou seja, no momento da redução do Estado, apoiaram-se no próprio Estado, ao colocarem um Banco público na posição de patrocinador das privatizações. Uma experiência única numa corrente de pensamento que tem horror ao Estado.

Nesse sentido, ao criticar as incoerências do liberalismo brasileiro, o trabalho procurou atacar os efeitos do Estado patrimonialista sobre a sociedade civil, ao destacar os prejuízos que esse modelo de dominação tradicional causa numa sociedade democrática. É um modelo que não consegue distinguir muito bem a esfera pública da esfera privada, comprometendo o funcionamento de uma República, já que os negócios privados não deveriam se apoiar excessivamente no Estado. A comunidade brasileira, por exemplo, não recebeu nenhum ganho pelas parcerias realizadas entre o BNDES e as empresas privadas, seja no caso das privatizações, ou no caso da Friboi. Desse modo, o advento da Constituição de 1988 pode significar um importante mecanismo de combate à resistência dos velhos estamentos que continuam presentes na sociedade e no aparelho de Estado. Assim, enfrentar o Estado patrimonialista é fazer que o liberalismo brasileiro tenha outro caráter, mais coerente com a democracia, com o constitucionalismo e com o livre desenvolvimento da sociedade civil.

\section{REFERÊNCIAS}

ANDERSON, Perry. Linhagens do Estado absolutista. São Paulo: Brasiliense, 2004. ARENDT, Hannah. A condição humana. Rio de Janeiro: Forense Universitária, 2005.

ASSIS, Machado de. Teoria do medalhão. In:

Paulo: Penguin \& Companhia das Letras, 2009.

. Papéis avulsos. São

BARROCAL, André. A carne não é fraca: a meteórica ascensão da Friboi e da família Batista, outra prova do capitalismo à brasileira. 2014. Disponível em: < http://www.cartacapital.com.br/revista/803/a-carne-nao-e-fraca-9831.html>. Acesso em: 25 ago. 2014.

BERCOVICI. Gilberto. A Constituição invertida: a Suprema Corte americana no combate à ampliação da democracia. Lua Nova, São Paulo, n. 89, p. 107$134,2013$.

BERMAN, Harold. Direito e Revolução: a formação da tradição jurídica ocidental. São Leopoldo: Unisinos, 2006.

BIONDI, Aloysio. O Brasil privatizado: um balanço do desmonte do Estado. São Paulo: Editora Fundação Perseu Abramo, 2000.

BOBBIO, Norberto. Sociedade Civil. In: ; MATTEUCCI, Nicola; PASQUINO, Gianfranco. Dicionário de Política. Brasília: Editora Universidade de Brasília: São Paulo: Imprensa Oficial do Estado, 2000. v. 2. 
CARDOSO, Fernando Henrique. Pensadores que inventaram o Brasil. São Paulo: Companhia das Letras, 2013.

CARVALHO, José Murilo de. A construção da Ordem: a elite política imperial; Teatro de Sombras: a política imperial. 2. ed. Rio de Janeiro: UFRJ, 1996.

CREVELD, Martin Van. The rise and decline of the state. Cambridge: Cambridge University Press, 2000.

FAORO, Raymundo. A aventura liberal numa ordem patrimonialista. Revista USP, São Paulo, n. 17, p. 14-29, 1993.

. Os donos do poder: formação do patronato político brasileiro. 3. ed. São Paulo: Globo, 2001.

. Prefácio. In: NOGUEIRA, Marco Aurélio. As desventuras do liberalismo: Joaquim Nabuco, a Monarquia e a República. Rio de Janeiro: Paz e Terra, 1984.

FREYRE, Gilberto. Casa grande e senzala: formação da família brasileira sob o regime de economia patriarcal. Rio de Janeiro: Record, 2001.

HELD, David. Modelos de democracia. Madrid: Alianza Editorial, 2006.

HOBBES, Thomas. Leviatã ou Matéria, forma e poder de um estado eclesiástico e civil. 2. ed. São Paulo: Abril Cultural, 1979.

HOLANDA, Sérgio Buarque de. Raízes do Brasil. 26. ed. São Paulo: Companhia das Letras, 1995.

KANTOROWIKCZ, Ernst Hartwig. Os dois corpos do rei: um estudo sobre teologia política medieval. São Paulo: Companhia das Letras, 1998.

KOSELLECK, Reinhart. Crítica e crise: uma contribuição a patogênese do mundo burguês. Rio de Janeiro: Eduerj: Contraponto, 1999.

LEITE, Dante Moreira. O caráter nacional brasileiro: história de uma ideologia. 3. ed. São Paulo, Pioneira, 1976.

LOCKE, John. The second treatise of government. New York: The Liberal Arts, 1952.

LOSURDO, Domenico. Contra-história do liberalismo. Aparecida: Ideias \& Letras, 2006.

MARX, Karl. Contribuição à crítica da economia política. São Paulo: Martins Fontes, 1983.

. O 18 de brumário de Luís Bonaparte. São Paulo: Boitempo, 2011.

MATTEUCCI, Nicola. Organización del poder y liberdad: historia del constitucionalismo moderno. Madrid: Trotta, 1998. 
MERQUIOR, José Guilherme. As ideias e as formas. Rio de Janeiro: Nova Fronteira, 1981.

. O liberalismo: antigo e moderno. Rio de Janeiro: Nova Fronteira, 1991.

NUNES, Avelãs. As voltas que o mundo dá...: reflexões a propósito das aventuras e desventuras do Estado Social. Rio de Janeiro: Lumen Juris, 2011.

PRADO JÚNIOR, Caio. Evolução política do Brasil: colônia e império. São Paulo: Brasiliense, 1983.

REALE, Giovane; ANTISERI, Dario. História da filosofia I: do Romantismo até nossos dias. São Paulo: Paulus, 1990.

RICUPERO, Bernardo; FERREIRA, Gabriela Nunes. Raymundo Faoro e as interpretações do Brasil. Perspectivas: Revista de Ciências Sociais, Araraquara, v. 28, p. 37-55, 2005.

SÓFOCLES. Antígona. 5. ed. Rio de Janeiro: Jorge Zahar Editor Ltda., 1996.

STRECK, Lenio Luiz. Hermenêutica Jurídica E(m) Crise. 10. ed. Porto Alegre: Livraria do Advogado, 2011.

VIANA, Oliveira. Populações meridionais no Brasil. Populações rurais do centro-sul. In: SANTIAGO, Silviano (Org.). Intérpretes do Brasil. Rio de Janeiro: Nova Aguilar, 2000. v. 1.

WEBER, Max. Economia y Sociedad. Esbozo de sociología comprensiva. México: Fondo de Cultura Económica, 1999.

SÓFOCLES. Antígona. 5. ed. Rio de Janeiro: Jorge Zahar Editor Ltda., 1996. p. 204.

Ibid., p. 204.

3 HOLANDA, Sérgio Buarque de. Raízes do Brasil. 26. ed. São Paulo: Companhia das Letras, 1995. p. 141.

4 CARDOSO, Fernando Henrique. Pensadores que inventaram o Brasil. São Paulo: Companhia das Letras, 2013.p. 138-139.

5 Ibid., p. 139.

6 LEITE, Dante Moreira. O caráter nacional brasileiro: história de uma ideologia. 3. ed. São Paulo, Pioneira, 1976.

7 Ibid., p. 293.

8 Segundo Bernardo Ricupero e Gabriela Nunes Ferreira, "o diferencial na explicação do Brasil de Faoro não está, entretanto, simplesmente no uso de categorias weberianas, mas na maneira como ele maneja essas referências, enfocando, por exemplo, certas questões e não outras. Aqui é útil a comparação com Sérgio Buarque de Holanda. Raízes do Brasil já havia utilizado ferramentas teóricas weberianas para analisar a experiência brasileira. No entanto, como o próprio Faoro insiste, a maneira de o historiador paulista entender o patrimonialismo em seu livro de estreia ainda pertence fundamentalmente a outro momento do pensamento social e político brasileiro, aquele que, dentro da interpretação privatista, insistia na influência do patrimonialismo na formação da sociedade brasileira. Ou melhor, Holanda vê o comportamento do funcionário patrimonial como uma extensão, em direção a outras esferas, das práticas prevalecentes na família patriarcal, o que caracterizaria uma 'invasão do público pelo privado'. A maneira de Os donos do poder interpretar o patrimonialismo é, porém, diferente e até oposta a de Raízes do Brasil. Para Faoro, o dominante no Brasil não é o ambiente doméstico, onde se desenvolve o patriarcalismo, mas o estatal, ao qual está relacionado o aparecimento do patrimonialismo". RICUPERO, Bernardo; 
FERREIRA, Gabriela Nunes. Raymundo Faoro e as interpretações do Brasil. Perspectivas: Revista de Ciências Sociais, Araraquara, v. 28, p. 51, 2005.

9 De acordo com José Murilo de Carvalho, enquanto na Inglaterra a aristocracia precisava menos da burocracia estatal para se manter, em Portugal, a aristocracia sempre dependeu do Estado para sobreviver, apoiando-se na máquina burocrática para preservar seus privilégios. Segundo ele, "a aristocracia inglesa não dependia do emprego público para sustento material. $\mathrm{O}$ que ela prestava era quase um serviço litúrgico, para usar a expressão weberiana, uma vez que podia viver das gordas rendas de suas terras. A de Portugal dependia cada vez mais do emprego para sobrevivência, donde sua dependência do Estado e seu crescente caráter parasitário". CARVALHO, José Murilo de. A construção da Ordem: a elite política imperial; Teatro de Sombras: a política imperial. 2. ed. Rio de Janeiro: UFRJ, 1996. p. 27.

10 FAORO, Raymundo. Os donos do poder: formação do patronato político brasileiro. 3. ed. São Paulo: Globo, 2001. p. 285-301.

11 MARX, Karl. O 18 de brumário de Luís Bonaparte. São Paulo: Boitempo, 2011.

12 RICUPERO, Bernardo; FERREIRA, Gabriela Nunes. Raymundo Faoro e as interpretações do Brasil. Perspectivas: Revista de Ciências Sociais, Araraquara, v. 28, p. 37-55, 2005.

13 De acordo com Max Weber, diferentemente do estamento burocrático, a burocracia se organiza como uma camada profissional capaz de assegurar o bom funcionamento do Estado e da administração pública. Desse modo, a burocracia não invade e dirige a esfera econômica, política e financeira, como ocorre com o estamento, mas deve aparecer como um aparelhamento neutro em qualquer tipo de Estado ou em qualquer forma de organização do poder, permitindo a realização do serviço público de maneira profissional e técnica, distanciando-se das influências político-partidárias. Assim, nos termos de Weber, a burocracia deve ordenar o comportamento humano por meio do exercício da autoridade racional-legal, para o atendimento de objetivos organizacionais gerais, a partir de uma rigorosa divisão de tarefas, com a criação de regras detalhadas e de uma hierarquia que possa garantir sua execução. WEBER, Max. Economia y Sociedad. Esbozo de sociología comprensiva. México: Fondo de Cultura Económica, 1999.

14 CARDOSO, Fernando Henrique. Pensadores que inventaram o Brasil. São Paulo: Companhia das Letras, 2013. p. 231.

15 CREVELD, Martin Van. The rise and decline of the state. Cambridge: Cambridge University Press, 2000.

16 KANTOROWIKCZ, Ernst Hartwig. Os dois corpos do rei: um estudo sobre teologia política medieval. São Paulo: Companhia das Letras, 1998.

17 BERMAN, Harold. Direito e Revolução: a formação da tradição jurídica ocidental. São Leopoldo: Unisinos, 2006.

18 MATTEUCCI, Nicola. Organización del poder y liberdad: historia del constitucionalismo moderno. Madrid: Trotta, 1998. p. 41.

19 Matteucci destaca que essa modalidade de Estado, definida como absoluta por seus teóricos, não deveria ser tratada como arbitrária ou despótica, já que prevalecia nela a lógica da racionalidade técnica e não o mero capricho do monarca. O poder do rei era indivisível e incontrolável, mas, ao mesmo tempo, limitado, pois o ele deveria governar e decidir apenas depois de ouvir o parecer dos órgãos institucionais com funções específicas. Ibid., p. 39-40.

20 Ao contrário do posicionamento assumido neste artigo, o historiador marxista, Perry Anderson, analisou a formação do Estado absolutista como mera expressão dos interesses políticos e econômicos da aristocracia, que, ao criar um poder político centralizado, apenas buscou assegurar seu próprio domínio social frente à decadência do modelo de dominação (servidão) presente no modo de produção feudal. Segundo ele, "Com a comutação generalizada das obrigações, transformadas em rendas monetárias, a unidade celular de opressão política e econômica do campesinato foi gravemente debilitada e ameaçada de dissociação (o final deste processo foi o 'trabalho livre' e o 'contrato salarial'). O poder de classe dos senhores feudais estava assim diretamente em risco com o desaparecimento gradual da servidão. O resultado disso foi um deslocamento da coerção político-legal no sentido ascendente, em direção a uma cúpula centralizada e militarizada - o Estado absolutista. Diluída no nível da aldeia, ela tornou-se concentrada no nível 'nacional'". Assim, é possível perceber que, para o historiador Perry Anderson, a formação do Estado absolutista foi, principalmente, resultado das contradições geradas pela estrutura econômica medieval (fim da servidão) e pelo desenvolvimento da luta de classes. ANDERSON, Perry. Linhagens do Estado absolutista. São Paulo: Brasiliense, 2004. p. 19.

21 KOSELLECK, Reinhart. Crítica e crise: uma contribuição a patogênese do mundo burguês. Rio de Janeiro: Eduerj: Contraponto, 1999. p. 21. 
22 MATTEUCCI, Nicola. Organización del poder y liberdad: historia del constitucionalismo moderno. Madrid: Trotta, 1998. p. 31.

23 De acordo com Lenio, o Leviatã hobbesiano está envolvido numa postura voluntarista própria da modernidade e, por isso, ele chega a afirmar que: "[...] em síntese, é o triunfo da vontade humana, questão que se perceberá no contrato de Hobbes, em que é a vontade dos homens que faz com que consigam vencer a barbárie". STRECK, Lenio Luiz. Hermenêutica Jurídica E $(\mathrm{m})$ Crise. 10. ed. Porto Alegre: Livraria do Advogado, 2011. p. 167.

24 HOBBES, Thomas. Leviatã ou Matéria, forma e poder de um estado eclesiástico e civil. 2. ed. São Paulo: Abril Cultural, 1979. p. 75.

25 REALE, Giovane; ANTISERI, Dario. História da filosofia I: do Romantismo até nossos dias. São Paulo: Paulus, 1990. p. 208.

26 HOBBES, Thomas. Leviatã ou Matéria, forma e poder de um estado eclesiástico e civil. 2. ed. São Paulo: Abril Cultural, 1979. p. 5.

27 MERQUIOR, José Guilherme. O liberalismo: antigo e moderno. Rio de Janeiro: Nova Fronteira, 1991. p. 16.

28 Um exemplo dessa situação pode ser encontrado na atuação conservadora da Suprema Corte estadunidense em seus primeiros anos de funcionamento. Bercovici ressalta que a preocupação com o despotismo das maiorias, presente nas formulações teóricas de James Madison, também tinha relação com a defesa dos interesses dos proprietários escravocratas frente aos pobres e aos marginalizados da sociedade estadunidense. Nesse sentido, além da preocupação dos pais fundadores com o controle do Poder Legislativo, por meio de uma Corte Constitucional, estava presente a necessidade de manutenção de uma democracia segregacionista. BERCOVICI. Gilberto. A Constituição invertida: a Suprema Corte americana no combate à ampliação da democracia. Lua Nova, São Paulo, n. 89, p. 107-134, 2013.

29 LOSURDO, Domenico. Contra-história do liberalismo. Aparecida: Ideias \& Letras, 2006.

30 MERQUIOR, José Guilherme. O liberalismo: antigo e moderno. Rio de Janeiro: Nova Fronteira, 1991. p. 18.

31 HELD, David. Modelos de democracia. Madrid: Alianza Editorial, 2006. p. 104-105.

32 LOCKE, John. The second treatise of government. New York: The Liberal Arts, 1952.

33 HELD, David. Modelos de democracia. Madrid: Alianza Editorial, 2006. p. 122.

34 MARX, Karl. Contribuição à crítica da economia política. São Paulo: Martins Fontes, 1983.

35 BOBBIO, Norberto. Sociedade Civil. In: __ ; MATTEUCCI, Nicola; PASQUINO, Gianfranco. Dicionário de Política. Brasília: Editora Universidade de Brasília: São Paulo: Imprensa Oficial do Estado, 2000.v. 2. p. 1209.

36 ARENDT, Hannah. A condição humana. Rio de Janeiro: Forense Universitária, 2005. p. 32.

37 Ibid., p. 31-37.

38 NUNES, Avelãs. As voltas que o mundo dá...: reflexões a propósito das aventuras e desventuras do Estado Social. Rio de Janeiro: Lumen Juris, 2011.p. 7.

39 MERQUIOR, José Guilherme. As ideias e as formas. Rio de Janeiro: Nova Fronteira, 1981. p. 287.

40 FAORO, Raymundo. Os donos do poder: formação do patronato político brasileiro. 3. ed. São Paulo: Globo, 2001.

41 FAORO, Raymundo. A aventura liberal numa ordem patrimonialista. Revista USP, São Paulo, n. 17, p. 14-29, 1993. p. 18.

42 WEBER, Max. Economia y Sociedad. Esbozo de sociología comprensiva. México: Fondo de Cultura Económica, 1999.

43 FAORO, Raymundo. A aventura liberal numa ordem patrimonialista. Revista USP, São Paulo, n. 17, p. 16, 1993.

44 Ibid., p. 17.

45 PRADO JÚNIOR, Caio. Evolução política do Brasil: colônia e império. São Paulo: Brasiliense, 1983.

46 FREYRE, Gilberto. Casa grande e senzala: formação da família brasileira sob o regime de economia patriarcal. Rio de Janeiro: Record, 2001.

47 FAORO, Raymundo. A aventura liberal numa ordem patrimonialista. Revista USP, São Paulo, n. 17, p. 17, 1993.

48 VIANA, Oliveira. Populações meridionais no Brasil. Populações rurais do centro-sul. In: SANTIAGO, Silviano (Org.). Intérpretes do Brasil. Rio de Janeiro: Nova Aguilar, 2000. v. 1.

49 CARDOSO, Fernando Henrique. Pensadores que inventaram o Brasil. São Paulo: Companhia das Letras, 2013. p. 228. 
50 FAORO, Raymundo. A aventura liberal numa ordem patrimonialista. Revista USP, São Paulo, n. 17, p. p. 26, 1993.

51 BIONDI, Aloysio. O Brasil privatizado: um balanço do desmonte do Estado. São Paulo: Editora Fundação Perseu Abramo, 2000. p. 11.

52 Ibid., p. 7.

53 Ibid., p. 12.

54 BARROCAL, André. A carne não é fraca: a meteórica ascensão da Friboi e da família Batista, outra prova do capitalismo à brasileira. 2014. Disponível em: <http://www.cartacapital.com.br/revista/803/a-carne-nao-e-fraca-9831.html>. Acesso em: 25 ago. 2014.

55 FAORO, Raymundo. Prefácio. In: NOGUEIRA, Marco Aurélio. As desventuras do liberalismo: Joaquim Nabuco, a Monarquia e a República. Rio de Janeiro: Paz e Terra, 1984. p. 11.

56 ASSIS, Machado de. Teoria do medalhão. In: das Letras, 2009. p. 101.

57 Ibid., p. 109.

\title{
LIBERALISM, THE BRAZILIAN WAY: THE EVERLASTING PROBLEM OF POLITICALLY ORIENTED CAPITALISM
}

\begin{abstract}
The article aims at attacking the effects that patrimonial State has on civil society, by highlighting the disadvantages that such model of traditional domination causes on a democratic society. It is a model that cannot properly distinguish the public sphere from the private, thus endangering the well-functioning of a Republic, since private businesses rely excessively on "partnerships" with the State. To confront patrimonialism is to change the character of Brazilian liberalism, making it more coherent with democracy, with constitutionalism and with the free development of civil society. These questions will be addressed in the present article, with the intent to reflect on the operation of the Brazilian State, its welcoming attitude towards liberalism and the possibilities to establish a republican regime in Brazil.
\end{abstract}

Keywords: Liberalism. Parliament. Patrimonialism. Civil Society. State.

Submetido: 1 mar. 2016

Aprovado: 13 maio 2016 